\title{
A conceptual model for empowering bank's human resources: A case study of Tejarat bank of Iran
}

\author{
Seyed Hossein Abtahi and Mohammad Reza Saadi*
}

Department of Management and Accounting, Allameh Tabatabai University, Tehran, Iran

\begin{tabular}{l}
\hline A R T I C L E I N F O \\
\hline Article history: \\
Received July 10, 2011 \\
Received in Revised form \\
October, 3, 2011 \\
Accepted 10 January 2012 \\
Available online \\
16 January 2012 \\
\hline Keywords: \\
Empowering employee \\
Self-effectiveness \\
Self-organization \\
Self-acceptance
\end{tabular}

\section{A B S T R A C T}

In this paper, we study the impact of structural factors on empowering employee in banking sector. The proposed study of this paper selects 1859 employees who work in 11 different areas of an Iranian bank called Tejarat. The proposed study of this paper discusses the finding associated with two departments of engineering and administration. Using a standard questionnaire, we gather the necessary data and the results are validated using Cronbach Alpha and factor analysis. We have used five different regression techniques to analyze the data and independent variables include complexity, formality and concentration. In addition, the dependent variables include self-effectiveness, self-organization, meaningful, self-acceptance and trust. The results indicate there is no correlation among structural components in engineering and administration areas.

(c) 2012 Growing Science Ltd. All rights reserved.

\section{Introduction}

During the past few decades, there have been many efforts on studying employees' behavior s, which are exclusive characteristics of any one (Koster et al., 2006; Noor, 2009). These investigations have been concentrated in four areas including job and leadership specification, personal characteristics and leadership behavior (Gautam et al., 2004; Šušnjar \& Zimanji, 2006). Organ (1995) explained fairness and organizational commitment as two important factors on organizational behavior based on a empirical study on 55 different studies. Meyer and Allen (1984) expressed there were three organizational commitments including moral, continuous and ethical commitments. According to Porter et al. (1974), commitment is integrated with employees' moral and emotional commitment where employees specify their identity based on an organizational objectives. Organizational commitment specifies anyone's efforts and willingness on reaching firm's objectives (Robbins, 1993). Joolideh et al. (2009) discussed that a suitable educational plan is designed based on the professional university professors who are capable of leading the business unit. Chughtai (2006) described that an existence commitment among university instructors could help organization increase their efficiencies.

* Corresponding author. Tel: +989121242572

E-mail addresses: saadi1001@yahoo.com (M. R. Saadi) 
Empowering practices has a long history and its history goes back to 1788, where it was described as a capability for giving a responsibility to a person who is qualified to perform a task (Naderi et al., 2007). For more than fifty years, empowerment practices have been a subject of extensive investigations (Nykodym et al., 1994). Samat et al. (2006) discussed that empowering employee could positively influence the quality of product and services. Employees with higher skills could extensively contribute to their organizations. Empowering activities include increasing employee commitment and the level of their contribution (McEwan \& Sackett, 1997; Chang, 1999; Val, 2003; Greasley et al., 2008). Spreitzer (1995) did a survey and found a positive correlation between empowering activities and job satisfaction. Meyerson et al. (2008) explained that when employee were empowered, he/she would feel more confident and could be expected well when a job is assigned to an employee who has already been under extensive training programs. Moye and Henkin (2006) investigated that these people could even make better decisions and could attract more customers. Lee et al. (2006) reported that empowering people could lead an organization to have more commitment people. Bhatnagar (2007) and Denton (1994) also provided some evidence to support Lee's study.

During the past few decades, the concept of organizational commitment has been improved (Putterill \& Rohrer, 1995). Organizational commitment is a concept, which has multi dimensional concept and it yields positive outcome on job including a remarkable reduction on work absence, citizenship organizational behavior, etc. (Bell \& Menguc, 2002; Chew, 2008). There are two methods on organizational commitment: The first one explains that commitment is a primary aim for continuous contribution to work and the second one is related to the level of interest among members of organization, which is the reflection of employees to organization (Jaramillo \& Nixson, 2005).

According to Alvani (1998), employees who have strong commitment to their organizations spend more time on their work and perform their jobs with more discipline. McCabe (2008) discussed that commitment is a vital factor for the success of an organization. Freund (2003) argued that a highly committed person increase organizations' efficiency more effectively. Aube et al. (2007) also support this concept and suggest increasing organizational commitment through employing people with strong motivations for long-term positions. There are several evidences, which indicate that organizational commitment has positive relationship with job satisfaction, job performance and employee's leave (Antonacopoulou, 2000; Hosseini et al., 2008).

\section{Proposed study}

The population of our survey covers 1859 people and the maximum error in our computation does not have to exceed five percent. The questions are in qualitative perspective from very low to very high in Likert scale (Likert, 1932). We also assigned weight values of one to five for different scales from very low to very high, respectively. Finally we assume the population follows a normal distribution. Therefore we could use the following formula to calculate the minimum number of sample size,

$$
n=\frac{N \times z_{\alpha / 2}^{2} \times p \times q}{\varepsilon^{2} \times(N-1)+z_{\alpha / 2}^{2} \times p \times q},
$$

where $N$ is the population size, $p=1-q$ represents the yes/no categories, $z_{\alpha / 2}$ is CDF of normal distribution and finally $\varepsilon$ is the error term. Since we have $p=0.5, z_{\alpha / 2}=1.96$ and $N=1859$, the number of sample size is calculated as $n=318$. In each area, we calculate the number of people using $n_{h}=\frac{N_{h}}{N} \times n$, where $N_{h}$ is the population size in each group. Since, in engineering field $N_{h}=239$, therefore we have $n_{h}=41$. Cronbach Alpha has been calculated for each groups of questions and the results are summarized in Table 1 as follows, 
Table 1

Cronbach Alpha $(\alpha)$ for each group of study

\begin{tabular}{llllllllll}
\hline Var. & Complexity & Formality & Concentration & $\begin{array}{l}\text { Self- } \\
\text { effectiveness }\end{array}$ & $\begin{array}{l}\text { Self- } \\
\text { organization }\end{array}$ & $\begin{array}{l}\text { Self- } \\
\text { acceptance }\end{array}$ & Meaningful & trust & Total \\
\hline $\mathrm{Q} \#$ & $1-4$ & $5-11$ & $12-14$ & $15-18$ & $19-23$ & $24-26$ & $27-29$ & $30-32$ & $1-32$ \\
$\alpha$ & 0.8011 & 0.8225 & 0.7905 & 0.7824 & 0.8614 & 0.7302 & 0.8748 & 0.8867 & 0.8187 \\
\hline
\end{tabular}

As we can observe from the results of Table 1, all Cronbach Alphas are well above 0.70, which implies the reliability of the proposed questionnaire results.

\section{Results}

\subsection{The impact of structural factors on self-effectiveness in engineering field}

The proposed study performs a regression analysis where the dependent variable $(y)$ is selfeffectiveness and the independent variables are complexity $\left(x_{1}\right)$, formality $\left(x_{2}\right)$ and effectiveness $\left(x_{3}\right.$ ), respectively. We consider the following three null hypotheses as follows,

$H_{0}$ : Complexity does not influence self-effectiveness $\beta_{1}=0$.

$H_{0}$ : Formality does not influence self-effectiveness $\beta_{1}=0$.

$H_{0}$ : Effectiveness does not influence self-effectiveness $\beta_{1}=0$.

The first step in regression analysis is to see whether the residuals are normally distributed. Fig. 1 shows details of our survey.

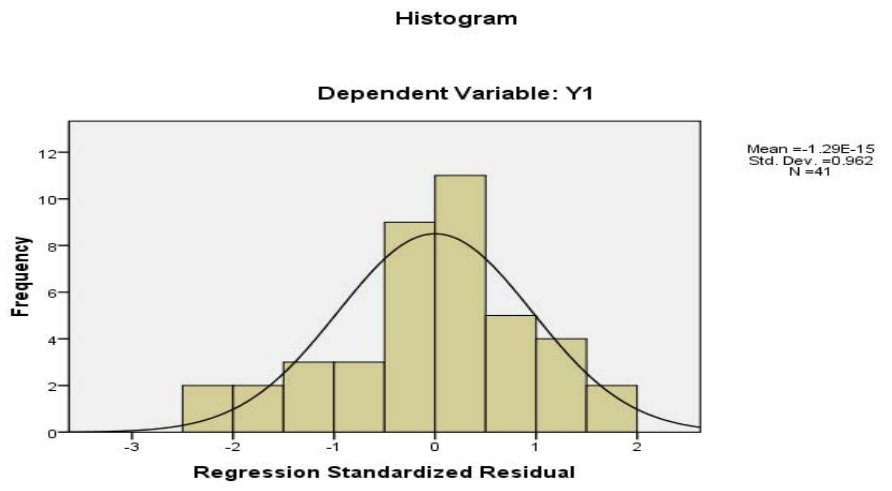

Fig. 1. Histogram of residuals

As we can observe from the figure, the residuals are fairly close to normal distribution. Table 2 shows details of ANOVA test on the regression analysis.

Table 2

ANOVA test results

\begin{tabular}{ccccccc}
\hline & Model & Sum of Squares & Df & Mean Square & F & Sig. \\
\hline \multirow{2}{*}{1} & Regression & 1.134 & 3 & .378 & .778 & $.514^{\mathrm{a}}$ \\
& Residual & 17.967 & 37 & .486 & \\
\cline { 2 - 7 } & Total & 19.101 & 40 & & \\
\hline
\end{tabular}

a. Predictors: (Constant), X3, X2, X1

b. Dependent Variable: Y1 
In addition, Table 3 shows details of our findings on regression analysis between the dependent variable and three independent variables.

Table 3

Regression analysis between dependent variable and independent variables

\begin{tabular}{|c|c|c|c|c|c|c|c|c|c|c|c|c|c|}
\hline \multirow[b]{2}{*}{ Mode } & & \multicolumn{2}{|c|}{$\begin{array}{l}\text { Unstandardized } \\
\text { Coefficients }\end{array}$} & \multirow{2}{*}{$\begin{array}{c}\begin{array}{r}\text { Standardized } \\
\text { Coefficients }\end{array} \\
\text { Beta } \\
\end{array}$} & \multirow[b]{2}{*}{$\mathrm{t}$} & \multirow[b]{2}{*}{ Sig. } & \multicolumn{2}{|c|}{$\begin{array}{l}\text { 95\% Confidence } \\
\text { Interval for B }\end{array}$} & \multicolumn{3}{|c|}{ Correlations } & \multicolumn{2}{|c|}{$\begin{array}{l}\text { Collinearity } \\
\text { Statistics }\end{array}$} \\
\hline & & B & Std. Error & & & & $\begin{array}{l}\text { Lower } \\
\text { Bound }\end{array}$ & $\begin{array}{l}\text { Upper } \\
\text { Bound }\end{array}$ & $\begin{array}{l}\text { Zero- } \\
\text { order }\end{array}$ & Partial & Part & Tolerance & VIF \\
\hline \multirow[t]{4}{*}{1} & (Constant) & 10.732 & 2.056 & & 5.220 & .000 & 6.567 & 14.898 & & & & & \\
\hline & $\mathrm{X} 1$ & -.073 & .133 & -.088 & -.547 & .588 & -.342 & .196 & -.094 & -.090 & -.087 & .978 & 1.022 \\
\hline & $\mathrm{X} 2$ & -.233 & .173 & -.214 & -1.343 & .187 & -.584 & .118 & -.209 & -.216 & -.214 & .998 & 1.002 \\
\hline & X3 & -.078 & .162 & -.078 & -.482 & .633 & -.406 & .250 & -.081 & -.079 & -.077 & .977 & 1.024 \\
\hline
\end{tabular}

a. Dependent Variable: Y1

The results of Table 2 and Table 3 specify that there is no meaningful relationship between the dependent variable and three independent variables and we can accept the null hypotheses with $\alpha=0.05$. Therefore, we conclude that the parameters of complexity, formality and effectiveness have no effects on self-effectiveness.

\subsection{The impact of self-structural factors on self-organization in engineering field}

The proposed study performs a regression analysis where the dependent variable $(y)$ is selforganization and the independent variables are complexity $\left(x_{1}\right)$, formality $\left(x_{2}\right)$ and effectiveness $\left(x_{3}\right.$ ), respectively. We consider the following three null hypotheses as follows,

$H_{0}$ : Complexity does not influence self-organization $\beta_{1}=0$.

$H_{0}$ : Formality does not influence self- organization $\beta_{1}=0$.

$H_{0}$ : Effectiveness does not influence self- organization $\beta_{1}=0$.

The first step in regression analysis is to see whether the residuals are normally distributed. Fig. 2 shows details of our survey.

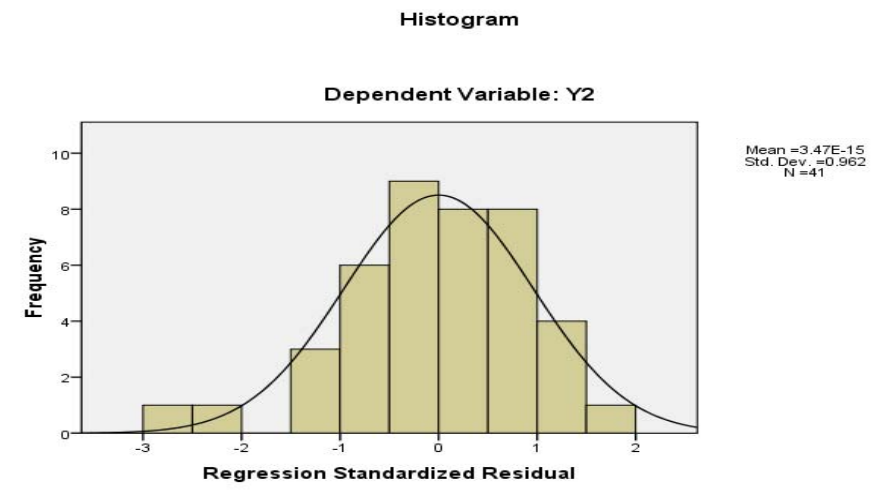

Fig. 2. Histogram of residuals

As we can observe from the figure, the residuals are fairly close to normal distribution. Table 4 shows details of ANOVA test on the regression analysis. 
Table 4

ANOVA test results

\begin{tabular}{ccccccc}
\hline & Model & Sum of Squares & Df & Mean Square & F & Sig. \\
\hline \multirow{2}{*}{1} & Regression & .465 & 3 & .155 & .626 & $.603^{\text {a }}$ \\
& Residual & 9.155 & 37 & .247 & & \\
\cline { 2 - 7 } & Total & 9.620 & 40 & & & \\
\hline
\end{tabular}

a. Predictors: (Constant), X3, X2, X1

b. Dependent Variable: Y1

In addition, Table 5 shows details of our findings on regression analysis between the dependent variable and three independent variables.

Table 5

Regression analysis between dependent variable and independent variables

\begin{tabular}{|c|c|c|c|c|c|c|c|c|c|c|c|c|c|}
\hline \multirow[b]{2}{*}{ Mode } & & \multicolumn{2}{|c|}{$\begin{array}{l}\text { Unstandardized } \\
\text { Coefficients }\end{array}$} & \multirow{2}{*}{$\begin{array}{c}\text { Standardized } \\
\text { Coefficients } \\
\text { Beta }\end{array}$} & \multirow[b]{2}{*}{$\mathrm{t}$} & \multirow[b]{2}{*}{ Sig. } & \multicolumn{2}{|c|}{$\begin{array}{l}\text { 95\% Confidence } \\
\text { Interval for B }\end{array}$} & \multicolumn{3}{|c|}{ Correlations } & \multicolumn{2}{|c|}{$\begin{array}{l}\text { Collinearity } \\
\text { Statistics }\end{array}$} \\
\hline & & B & Std. Error & & & & $\begin{array}{l}\text { Lower } \\
\text { Bound }\end{array}$ & $\begin{array}{l}\text { Upper } \\
\text { Bound }\end{array}$ & $\begin{array}{l}\text { Zero- } \\
\text { order }\end{array}$ & Partial & Part & Tolerance & VIF \\
\hline \multirow[t]{4}{*}{1} & (Constant) & 7.869 & 1.468 & & 5.362 & .000 & 4.896 & 10.843 & & & & & \\
\hline & $\mathrm{X} 1$ & -.070 & .095 & -.119 & -.733 & .468 & -.262 & .123 & -.136 & -.120 & -.118 & .978 & 1.022 \\
\hline & $\mathrm{X} 2$ & 110 & . 124 & . 143 & .889 & .380 & -.141 & .361 & .150 & .145 & .143 & 998 & 1.002 \\
\hline & X3 & -.066 & .116 & -.092 & -.570 & .572 & -.300 & .168 & -.116 & -.093 & -.091 & 977 & 1.024 \\
\hline
\end{tabular}

a. Dependent Variable: Y1

The results of Table 4 and Table 5 specify that there is no meaningful relationship between the dependent variable and three independent variables and we can accept the null hypotheses with $\alpha=0.05$. Therefore, we conclude that the parameters of complexity, formality and effectiveness have no effects on self-organization.

\subsection{The impact of self-structural factors on self-acceptance in engineering field}

The proposed study performs a regression analysis where the dependent variable $(y)$ is selfacceptance and the independent variables are complexity $\left(x_{1}\right)$, formality $\left(x_{2}\right)$ and effectiveness $\left(x_{3}\right)$, respectively. We consider the following three null hypotheses as follows,

$H_{0}$ : Complexity does not influence self-acceptance $\beta_{1}=0$.

$H_{0}$ : Formality does not influence self-acceptance $\beta_{1}=0$.

$H_{0}$ : Effectiveness does not influence self-acceptance $\beta_{1}=0$.

The first step in regression analysis is to see whether the residuals are normally distributed. Fig. 3 shows details of our survey.

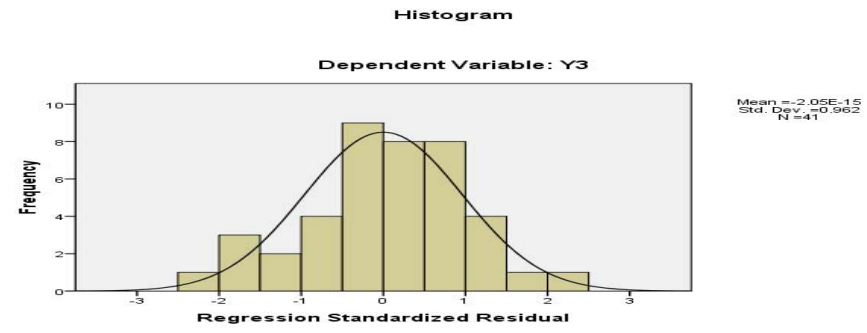

Fig. 3. Histogram of residuals 
As we can observe from the figure, the residuals are fairly close to normal distribution. Table 6 shows details of ANOVA test on the regression analysis.

Table 6

ANOVA test results

\begin{tabular}{clccccc}
\hline & Model & Sum of Squares & Df & Mean Square & F & Sig. \\
\hline \multirow{2}{*}{1} & Regression & .169 & 3 & .056 & .075 & $.973^{\text {a }}$ \\
& Residual & 27.788 & 37 & .751 & & \\
\cline { 2 - 7 } & Total & 27.957 & 40 & & & \\
\hline
\end{tabular}

a. Predictors: (Constant), X3, X2, X1

b. Dependent Variable: Y1

In addition, Table 7 shows details of our findings on regression analysis between the dependent variable and three independent variables.

Table 7

Regression analysis between dependent variable and independent variables

\begin{tabular}{|c|c|c|c|c|c|c|c|c|c|c|c|c|c|}
\hline \multirow[b]{2}{*}{ Mode } & & \multicolumn{2}{|c|}{$\begin{array}{l}\text { Unstandardized } \\
\text { Coefficients }\end{array}$} & \multirow{2}{*}{$\begin{array}{c}\begin{array}{c}\text { Standardized } \\
\text { Coefficients }\end{array} \\
\text { Beta }\end{array}$} & \multirow[b]{2}{*}{$\mathrm{t}$} & \multirow[b]{2}{*}{ Sig. } & \multicolumn{2}{|c|}{$\begin{array}{l}\text { 95\% Confidence } \\
\text { Interval for B }\end{array}$} & \multicolumn{3}{|c|}{ Correlations } & \multicolumn{2}{|c|}{$\begin{array}{l}\text { Collinearity } \\
\text { Statistics }\end{array}$} \\
\hline & & B & Std. Error & & & & $\begin{array}{l}\text { Lower } \\
\text { Bound }\end{array}$ & $\begin{array}{l}\text { Upper } \\
\text { Bound }\end{array}$ & $\begin{array}{l}\text { Zero- } \\
\text { order }\end{array}$ & Partial & Part & Tolerance & VIF \\
\hline \multirow{4}{*}{1} & (Constant) & 7.037 & 2.557 & & 2.752 & .009 & 1.856 & 12.218 & & & & & \\
\hline & $\mathrm{X} 1$ & .014 & .165 & .014 & .085 & .933 & -.321 & .349 & .009 & .014 & .014 & .978 & 1.022 \\
\hline & $\mathrm{x} 2$ & .097 & .215 & .074 & .449 & .656 & -.340 & .533 & .074 & .074 & .074 & .998 & 1.002 \\
\hline & X3 & -.025 & .202 & -.021 & -.124 & .902 & -.433 & .383 & -.022 & -.020 & -.020 & .977 & 1.024 \\
\hline
\end{tabular}

a. Dependent Variable: Y1

The results of Table 6 and Table 7 specify that there is no meaningful relationship between the dependent variable and three independent variables and we can accept the null hypotheses with $\alpha=0.05$. Therefore, we conclude that the parameters of complexity, formality and effectiveness have no effects on self-acceptance.

\subsection{The impact of self-structural factors on meaningful in engineering field}

The proposed study performs a regression analysis where the dependent variable $(y)$ is meaningful and the independent variables are complexity $\left(x_{1}\right)$, formality $\left(x_{2}\right)$ and effectiveness $\left(x_{3}\right)$, respectively. We consider the following three null hypotheses as follows,

$H_{0}$ : Complexity does not influence meaningful $\beta_{1}=0$.

$H_{0}$ : Formality does not influence meaningful $\beta_{1}=0$.

$H_{0}$ : Effectiveness does not influence meaningful $\beta_{1}=0$.

The first step in regression analysis is to see whether the residuals are normally distributed. Fig. 4 shows details of our survey.

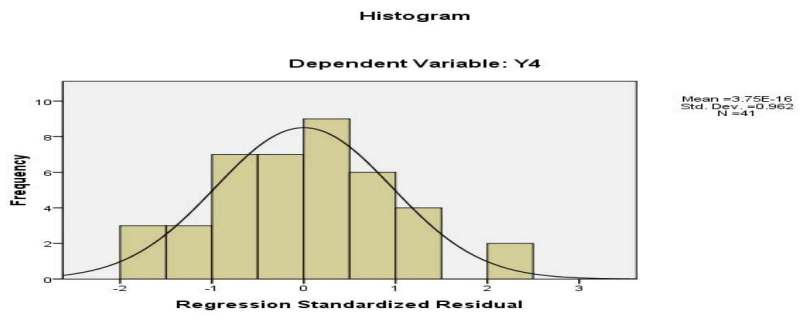

Fig. 4. Histogram of residuals 
As we can observe from the figure, the residuals are fairly close to normal distribution. Table 8 shows details of ANOVA test on the regression analysis.

Table 8

ANOVA test results

\begin{tabular}{clccccc}
\hline & Model & Sum of Squares & Df & Mean Square & F & Sig. \\
\hline \multirow{2}{*}{1} & Regression & .548 & 3 & .183 & .308 & $.819^{\mathrm{a}}$ \\
& Residual & 21.940 & 37 & .593 & & \\
\cline { 2 - 8 } & Total & 22.488 & 40 & & & \\
\hline
\end{tabular}

a. Predictors: (Constant), X3, X2, X1

b. Dependent Variable: Y1

In addition, Table 9 shows details of our findings on regression analysis between the dependent variable and three independent variables.

Table 9

Regression analysis between dependent variable and independent variables

\begin{tabular}{|c|c|c|c|c|c|c|c|c|c|c|c|c|c|}
\hline \multirow[b]{2}{*}{ Mode } & & \multicolumn{2}{|c|}{$\begin{array}{l}\text { Unstandardized } \\
\text { Coefficients }\end{array}$} & \multirow{2}{*}{$\begin{array}{c}\text { Standardized } \\
\text { Coefficients }\end{array}$} & \multirow[b]{2}{*}{$\mathrm{t}$} & \multirow[b]{2}{*}{ Sig. } & \multicolumn{2}{|c|}{$\begin{array}{l}\text { 95\% Confidence } \\
\text { Interval for B }\end{array}$} & \multicolumn{3}{|c|}{ Correlations } & \multicolumn{2}{|c|}{$\begin{array}{l}\text { Collinearity } \\
\text { Statistics }\end{array}$} \\
\hline & & B & Std. Error & & & & $\begin{array}{l}\text { Lower } \\
\text { Bound }\end{array}$ & $\begin{array}{l}\text { Upper } \\
\text { Bound }\end{array}$ & $\begin{array}{l}\text { Zero- } \\
\text { order }\end{array}$ & Partial & Part & Tolerance & VIF \\
\hline \multirow[t]{4}{*}{1} & (Constant) & 7.037 & 2.557 & & 2.752 & .009 & 1.856 & 12.218 & & & & & \\
\hline & $\mathrm{X} 1$ & .014 & . 165 & .014 & .085 & 933 & -.321 & .349 & .009 & .014 & .014 & .978 & 1.022 \\
\hline & $\mathrm{X} 2$ & . 097 & 215 & .074 & . 449 & .656 & -.340 & .533 & .074 & .074 & .074 & 998 & 1.002 \\
\hline & X3 & -.025 & .202 & -.021 & -.124 & .902 & -.433 & .383 & -.022 & -.020 & -.020 & .977 & 1.024 \\
\hline
\end{tabular}

a. Dependent Variable: Y1

The results of Table 8 and Table 9 specify that there is no meaningful relationship between the dependent variable and three independent variables and we can accept the null hypotheses with $\alpha=0.05$.

\subsection{The impact of trust on meaningful in engineering field}

The proposed study performs a regression analysis where the dependent variable $(y)$ is meaningful and the independent variables are complexity $\left(x_{1}\right)$, formality $\left(x_{2}\right)$ and effectiveness $\left(x_{3}\right)$, respectively. We consider the following three null hypotheses as follows,

$H_{0}$ : Complexity does not influence trust $\beta_{1}=0$.

$H_{0}$ : Formality does not influence trust $\beta_{1}=0$.

$H_{0}$ : Effectiveness does not influence trust $\beta_{1}=0$.

The first step in regression analysis is to see whether the residuals are normally distributed. Fig. 5 shows details of our survey.

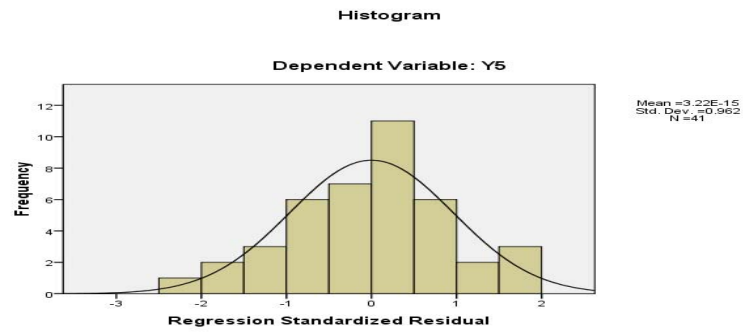

Fig. 5. Histogram of residuals 
As we can observe from the figure, the residuals are fairly close to normal distribution. Table 10 shows details of ANOVA test on the regression analysis.

Table 10

ANOVA test results

\begin{tabular}{llllllll}
\hline & Model & Sum of Squares & Df & Mean Square & F & Sig. \\
\hline \multirow{2}{*}{1} & Regression & .687 & 3 & .229 & .381 & $.767^{\text {a }}$ \\
& Residual & 22.245 & 37 & .601 & & \\
\cline { 2 - 7 } & Total & 22.932 & 40 & & & \\
\hline
\end{tabular}

a. Predictors: (Constant), X3, X2, X1

b. Dependent Variable: Y1

In addition, Table 11 shows details of our findings on regression analysis between the dependent variable and three independent variables.

Table 11

Regression analysis between dependent variable and independent variables

\begin{tabular}{|c|c|c|c|c|c|c|c|c|c|c|c|c|c|}
\hline \multirow[b]{2}{*}{ Mode } & & \multicolumn{2}{|c|}{$\begin{array}{l}\text { Unstandardized } \\
\text { Coefficients }\end{array}$} & \multirow{2}{*}{$\begin{array}{c}\begin{array}{c}\text { Standardized } \\
\text { Coefficients }\end{array} \\
\text { Beta }\end{array}$} & \multirow[b]{2}{*}{$\mathrm{t}$} & \multirow[b]{2}{*}{ Sig. } & \multicolumn{2}{|c|}{$\begin{array}{l}\text { 95\% Confidence } \\
\text { Interval for B }\end{array}$} & \multicolumn{3}{|c|}{ Correlations } & \multicolumn{2}{|c|}{$\begin{array}{l}\text { Collinearity } \\
\text { Statistics }\end{array}$} \\
\hline & & B & Std. Error & & & & $\begin{array}{l}\text { Lower } \\
\text { Bound }\end{array}$ & $\begin{array}{l}\text { Upper } \\
\text { Bound }\end{array}$ & $\begin{array}{l}\text { Zero- } \\
\text { order }\end{array}$ & Partial & Part & Tolerance & VIF \\
\hline \multirow{4}{*}{1} & (Constant) & 9.729 & 2.288 & & 4.253 & .000 & 5.093 & 14.364 & & & & & \\
\hline & $\mathrm{X} 1$ & .004 & .148 & .005 & .029 & .977 & -.295 & .304 & -.014 & .005 & .005 & .978 & 1.022 \\
\hline & $\mathrm{X} 2$ & -.118 & .193 & -.099 & -.611 & .545 & -.508 & .273 & -.093 & -.100 & -.099 & .998 & 1.002 \\
\hline & X3 & -.162 & .180 & -.147 & -.897 & .375 & -.527 & .204 & -.142 & -.146 & -.145 & .977 & 1.024 \\
\hline
\end{tabular}

a. Dependent Variable: Y1

The results of Table 10 and Table 11 specify that there is no meaningful relationship between the dependent variable and three independent variables and we can accept the null hypotheses with $\alpha=0.05$. Therefore, we conclude that the parameters of complexity, formality and effectiveness have no effects on trust.

\section{Conclusion}

In this paper, we have presented an empirical survey to investigate the impact of structural factors on empowering employee in banking sector. The proposed study of this paper selected 1859 employees who work in 11 different areas of an Iranian bank called Tejarat. The proposed study of this paper discussed the finding associated with engineering department. Using a standard questionnaire, we gathered the necessary data and the results were validated using Cronbach Alpha and factor analysis. We have used five various regression techniques to analyze the data and independent variables include complexity, formality and concentration. In addition, the dependent variables include selfeffectiveness, self-organization, meaningful, self-acceptance and trust. The results indicated there was no correlation among structural components in engineering and administration areas.

\section{Acknowledgment}

The authors would like to thank the anonymous referees for their constructive comments on earlier version of this work.

\section{References}

Alvani, M., \& Memarzadeh, G.H. (1998). Organizational behavior. Tehran . publication Morvarid(translated in Persian).

Antonacopoulou, E.P. (2000). Reconnecting education, development training through learning: A holographic perspective. Education + Training, 42 (4/5), 255-263. 
Aube, C., Rousseau.V., \& Morin, E.M. (2007). Perceived organizational support and organizational commitment The moderating effect of locus of control and work autonomy. Journal of Managerial Psychology, 22 (5), 479-495.

Bell, S.J., \& Menguc, B. (2002), The employee-organization relationship, organizational citizenship behaviours , and superior service quality. Journal of Retailing, 78(2), 131-146.

Bhatnagar, J. (2007). Predictors of organizational commitment in India: strategic HR roles, organizational learning capability and psychological empowerment. The International Journal of Human Resource Management, 18 (10), 1782-1812.

Chang, E. (1999). Career commitment as a complex moderator of organizational commitment and turnover intention. Human Relations, 52(10), 1257-1278.

Chew, J., \& Chan, C.C.A. (2008). Human resource practices, organizational commitment and intention to stay. International Journal of Manpower, 29( 6),503-522.

Chughtai, A.A. \& Zafar, S. (2006). Antecedents and Consequences of Organizational Commitment among Pakistani university teachers. Applied H.R.M. Research, 11(1), 39-64.

Cronbach, L. J. (1951). Coefficient alpha and the internal structure of tests. Psychometrika, 16(3), 297-334.

Denton, D.K. (1994). Empowerment through employee involvement and participation Ford's development and training programs. Empowerment in Organizations, 2(2), 22-28.

Freund, A., \& Carmeli, A. (2003). An empirical assessment: reconstructed model for five universal forms of work commitment. Journal of Managerial Psychology,18(7), 708-725.

Gautam,T, Dick, R.V., Wagner, U., Upadhyay, N., \& Davis, A.J. (2004). Organizational citizenship behavior and organizational commitment in Nepal. sciencelinks.jp/j-east/article/.

Greasley, K., Bryman, A., Dainty, A., Price, A., Naismith, N., \& Soetanto, R. (2008). Understanding empowerment from an employee perspective What does it mean and do they want it?. Team Performance Management, 14 (1/2), 39-55.

Hosseini, M., Mehdizadeh Ashrafi, A.(2010). Identification of effective factors on organizational commitment . Management Journal. No 18.

Jaramillo, F., \& Nixson, R.(2005).The effect of law enforcement stress on organizational commitment. An International Journal of Police Strategic and Management, 28, 321-336.

Joolideh, F. \& Yeshodhara, K. ( 2009). Organizational commitment among high school teachers of India and Iran .Journal of Educational Administration, 47 (1), 127-136.

Koster, F. \& Sanders, K.(2006). Organisational citizens or reciprocal relationships? An empirical comparison. Personal Review, 35 (5), 519-537.

Lee, Y.K., Nam, F.H., Park, D.H., \& Lee, K.A. (2006). What factors influence customer-oriented prosocial behavior of customer-contact employees?. Journal of Services Marketing, 20(4), 251264.

Likert, R. (1932). A Technique for the Measurement of Attitudes. Archives of Psychology, 140, 1-55.

Liu, A.M.M., Chiu, W.M., \& Fellows, R. (2007). Enhancing commitment through work empowerment. Engineering Construction and Architectural Management,14(6), 568-580.

Liu, C.M. (2007). The early employment influences of sales representatives on the development of organizational commitment. Employee Relations, 29(1), 5-15.

Liu, Y. (2009). Perceived organizational support and expatriate organizational citizenship behavior: The mediating role of affective commitment towards the parent company. Personnel Review, 38 (3), 307-319.

McCabe, T.J., \& Garavan, T.N. (2008). A study of the drivers of commitment amongst nurses The salience of training, development and career issues. Journal of European Industrial Training, 32 (7), 528-568.

McEwan, A.M., \& Sackett, P. (1997). Theoretical considerations of employee empowerment within computer integrated manufacturing production. Empowerment in Organizations, 5 (3), 129-138.

Meyer, J.P. \& Allen N.J. (1984). Testing the "Side Bet Theory" of organizational commitment: Some methodological considerations. Journal of Applied Psychology, 67, 372-278. 
Meyerson, S.L., \& Kline.T.J.B. (2008). Psychological and environmental empowerment: antecedents and consequences. Leadership \& Organization Development Journal ,29 (5), 444-460.

Moye, M.J., \& Henkin, A.B. (2006). Exploring associations between employee empowerment and interpersonal trust in managers. Journal of Management Development, 25(2), 101-117.

Naderi, N., Rajaeepoor, S., \& Jamshidian, A. (2007). Concepts and strategies of empowering employees . Tadbir journal, 186.

Noor, A. (2009). Examining organizational citizenship behavior as the outcome of organizational commitment: a study of universities teachers of Pakistan. Army public college of management sciences(APCOMS).

Organ, D. W., \& Ryan K. (1995) A meta-analytic review of attitudinal and dispositional predictors of organizational citizenship behavior. Personnel Psychology, 48, 775-802.

Putterill, M.S., \& Rohrer, T.C. (1995). A causal model of employee commitment in a manufacturing setting. International Journal of Manpower, 16(5/6), 56-69.

Robbins, S. (1993). Organizational behavior. $6^{\text {th }}$ ed. Prentice-Hall.

Samat, N., Ramayah, T., \& Saad, N.M. (2006). TQM practices, service quality, and market orientation some empirical evidence from a developing country. Management Research News, 29(11), 713-728.

Spreitzer, G.M. (1995). Psychological empowerment in the workplace: Dimensions, measurement, and validation. The Academy of Management Journal, 38(5), 1442-1465.

Šušnjar, Š. G., \& Zimanji, V. (2006). Menadžment ljudskih resursa, Ekonomski fakultet, Subotica.

Val, M.P.D., \& Lloyd, B. (2003). Measuring Empowerment. Leadership and Organization Development Journal, 24(2), 102-108. 